\title{
WestVirginiaUniversity
}

THE RESEARCH REPOSITORY @ WVU

West Virginia Agricultural and Forestry Experiment

Davis College of Agriculture, Natural Resources

Station Bulletins

And Design

$1-1-1889$

\section{The creamery industry : its adaptability to West Virginia}

\author{
A. C. Magruder
}

Follow this and additional works at: https://researchrepository.wvu.edu/ wv_agricultural_and_forestry_experiment_station_bulletins

\section{Digital Commons Citation}

Magruder, A. C., "The creamery industry : its adaptability to West Virginia" (1889). West Virginia Agricultural and Forestry Experiment Station Bulletins. 4.

https://researchrepository.wvu.edu/wv_agricultural_and_forestry_experiment_station_bulletins/4 @ WVU. It has been accepted for inclusion in West Virginia Agricultural and Forestry Experiment Station Bulletins by an authorized administrator of The Research Repository@WVU. For more information, please contact ian.harmon@mail.wvu.edu. 



\title{
BULLETIN NO.4
}

\author{
OF THE.
}

\section{WEST VIRGINIA}

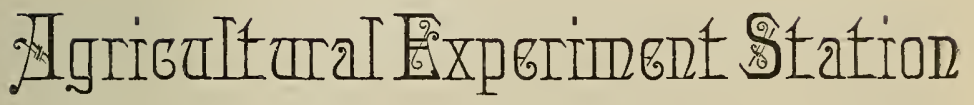

\author{
$\mathrm{A} T$
}

MORGANTOWN, W:VA.,

IIARCH, 1889.

The Creamery Industry: Its Adaptability to West Virginia.

\author{
BY A. C. MAGRUDER.
}

JOHN A. WYERS, Director. 
Digitized by the Internet Archive in 2010 with funding from Lyrasis Members and Sloan Foundation 
Board of Regents of West Va. University.

Dist. Name of Regent.

P. O. Address.

1. J. B. SOMMERVILLE, - - - Wheeling.

2. CLARENCE L. SMITH, - - - - Fairmont.

3. PEREGRIN HAYS, - - - - - Glenville.

4. D. D. JOHNSON, - - - - Longreach.

5. JOHN G. SCHILLING, - - - - - Spencer.

6. EDWARD A. BENNETT, - - Huntington.

7. WIRT A. FRENCH, - - _ _ - Princeton.

8. M. J. KESTER, - - - - - _ Union.

9. D. C. GALLAHER, - - - - Charleston.

10. THOMAS J. FARNSWORTH, - B Buckhannon.

11. JOSEPH MORELAND, - - - Morgantown.

12. JOHN A. ROBINSON, - - Patterson's Depot.

13. DR. W. W. BROWN, - - - - Charlestown.

Members of the Executive Board.

JOHN A. ROBINSON, CLARENCE L. SMITH,
J. B. SOMMERVILLE, THOMAS J. FARNSWORTH,

Members of the Building Committee.

JOHN. A. ROBINSON, D. D. JOHNSON,
CLARENCE L. SMITH, JOHN G. SCHILLING,

W. W. BROWN.

Treasurer,

JOHN I. HARVEY,
Secrotury,

W. P. WILLEY 
Officers and Staff of the West Virginia Experiment Station,

Director and Chemist,

Dairyman,

Assistant Chemist,

“

،

Meteorologist and Assistant Chemist,

Microscopist,

Ornithologist,

Botanist,

Veterinarian,

Agriculturist,

Horticulturist,

Stenographer and Book-keeper,

JOHN A. Myers.

A. C. MAGRUDER.

\author{
A. R. Whitehill. \\ J. W. Hartigan. \\ William D. Doan.
}




\section{CHE CREAMER Y INDUSTRY : ITS ADAPTABILITY TO WEST VIRGINIA.}

\section{BY A, C. MAGRUDER.}

While visiting the different sections of this State in the interst of the Creamery Department of the Experiment Station, ny attention has been directed to the natural advantages posessed by the State which adapts it to the Creamery Industry ather than to the present methods of farming.

Within reach of lines of transportation there is scarcely a ortion of the cultivated lands of this State one mile square that nay not furnish in liberal quantities the three essentials to this ndustry, viz., good cows, good pastures, and pure water. These hree factors have been examined carefully, and I can see no lausible reason why our farmers should prefer to continue in he old and beaten paths.

The arable lands in the greater part of our State are very illy, and it is with great difficulty in some sections that they re cultivated. Still this system of farming is pursued instead if the much more economic system of converting these steep ands into pastures, with a good cow as the improved machine o convert the grass into milk, a much more marketable product han wheat, corn, or hay.

That our lands can be converted into good pastures is a truth aade manifest to us not only by the enterprising farmers of our ister States, who each year are turning the poorer lands into asture, while only the richer are cropped, but by a few of West Tirginia's sons who have seen that cropping the soil year after ear without returning plant-food is exhausting the land to such n extent that they are not capable of producing one-half of the rop that was formerly harvested.

Am I too bold in asserting that our bottom lands, as well as he hillsides can be made more remunerative by pasturing and rroducing butter and cheese than by the present system of 
farming, which each year robs the soil of plant food, insteact of returning to the soil those elements essential to the best development of plant growth? A comparison of the results of the two systems on a given amount of land for a certain number of years-say ten acres for a decade-will be the most efficient means of substantiating this claim.

The following figures used in estimating the yield and value of wheat and corn are the average of quite a number of estimates made by intelligent and reliable agriculturists of different parts of this State, while those used in estimating the value of creamery products are obtained from the current prices of the day, and are substantiated by experience and experiments in different creameries throughont the country :

Estimated yield and price of wheat per year for ten years:

1st year, 35 bushels per acre, 10 acres, 350 bu., at $\$ 1$ per bu .... $\$ 350$

\begin{tabular}{|c|c|c|c|c|c|c|c|c|c|c|}
\hline $2 d \quad$ " & 30 & " & 6 & “6 & " & ". & $300 ،$ & ، " ، & ، & " \\
\hline "6 & 25 & " & "، & ، & ، & “" & 250 " & “" ، & "، & ." \\
\hline ith & 20 & " & 66 & " & " & "، & 200 " & 6. & " & ، \\
\hline th & $1 \mathrm{~s}$ & "6 & $\because$ & “6 & "6 & ، & $180 ،$ & 6 6 6 & " & " \\
\hline Sth & 17 & " & " & " & " & “ & $170 ،$ & ، 6 & ، & ، \\
\hline "6 & 16 & ، & ، & "6 & 6 & "، & 160 " & ، 6 6 & "، & ، \\
\hline .6 & 15 & ، & " & " & “ & ، & $150 ،$ & " " ، & " & ، \\
\hline ، & 14 & "، & " & "6 & $" 6$ & ، & 110 " & “ ، " & $":$ & " \\
\hline 10th" & 13 & " & ، & ، & ، & . & 130 ، & 6، ، & ، & "، \\
\hline
\end{tabular}

The wheat straw sold will have a value of $\$ 250.00$, giving a total value of $\$ 2,2$ So as gross receipts for the whole crop of ten acres in ten years.

Estimated yield and price of corn per year for ten years :

1st year, 70 bu. per acre, 10 aeres, 700 bu., at 50 ct - jer bu . . . \$350

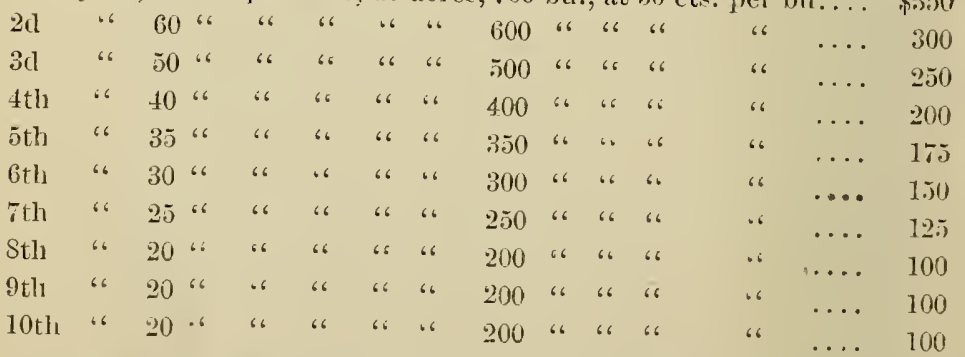

Fodder for ten years, equal in value to $\$ 300$, giving a total 
of $\$ 2,150$ as gross receipts for corn crop of ten acres in ten rears.

In the above estimate it will be noticed that wheat is quoted it one dollar and corn at 50 cents per bushel each year for the ntire time. While this may have been the case for the last lecade, we cannot count on it as a fixed price to be received ach year in future, for we are all too well acquainted with the luctuations of prices which constantly occur.

What can be done on the same ten acres should they be conerted into pasture? This amount of land will keep four good lairy cows, and by a good cow we do not have reference to ne that gives from two to eight pints of milk per day, but one hat will fall very little below the standard, which is as follows:

'irst three months after becoming fresh, 31/2 gal. per day, 3 mo., 315 gal. iext four:

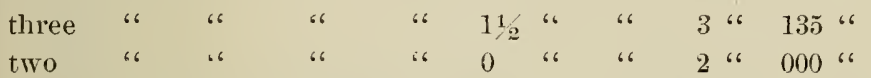

In twelve months, or one year, she will have produced 690 allons of milk, which will make 230 pounds of butter, grantig that we obtain one pound of butter from evcry three galsns of milk. The 230 pounds of butter sold at 25 cents per ound, the average price for the creamery product, gives as eceipts for butter alone per cow per year $\$ 57.50$.

st year 4 cows will produce in butter 920 lbs., at 25 cts. per lb. $\$ 230$

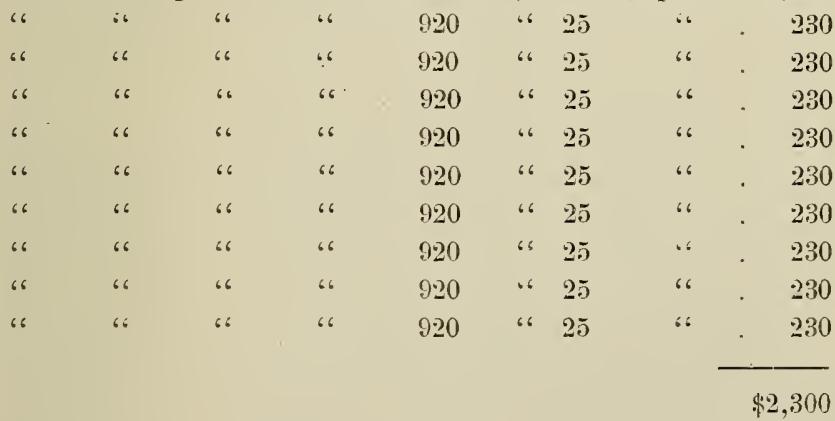

From this it will be seen that the four cows would produce 3 ten years 9,200 pounds of butter, which sold at 25 cents per ound, would amount to $\$ 2,300$. 
Butter is not the only marketable product in milk, for out of every $25 \frac{1}{2}$ pounds of whole sweet milk, from which we obtain I pound of butter, there remains $2 \mathrm{I} \frac{1}{4}$ pounds of sweet skim milk, when the centrifugal cream separator is used to extract the cream from the milk, the separation being best made while the milk is warm with animal heat. This skim milk being perfectly sweet, may be made into what is known as Schweitzer cheese, but as cheese can be manufactured only from the first of May to the last of October, we must reckon six months in each year, or five years in the ten, to be devoted to the manufacture of cheese from skim milk. Thus only one-half or 977,500 pounds of the skim milk, which would have accumulated in the ten years, can go to the manufacture of cheese. From this amount of milk can be made $S, S \$ 6.36$ pounds of cheese, assuming eleven pounds of milk to one of cheese, which sold at 4 cents per pound would amount to $\$ 355.45$. From the remaining half of the skim milk can be obtained equally as good results, as experiments have shown that sweet skim milk converted into pork is as remunerative as when made into cheese. In fact, considering the extra expense of a cheese-maker in connection with the business (for certainly one man cannot make both butter and cheese for a creamery from $\mathrm{r} 50$ to 400 cows), it is more economical to feed the entire lot of skim milk to hogs than manufacture it into cheese, and then the man who runs the creamery, with little extra labor, can attend to a drove of roo or 150 hogs.

Let us assume the result obtained by converting the one-half of the shim milk into pork just equal in value to that converted in to cheese, though considering the expense of each, results will be much in faror of feeding. We then have twice the amount of the receipts for cheese, or $\$ 710.90$, as total receipts for skim milk during the decade. From the cream which produced the 9,200 pounds of butter, we obtain $3,737.5$ gallons of butter-milk, which valued at only 2 cents per gallon as hog feed (at least 5 cents being obtained when put on the market), we have $\$ 74.75$ as proceeds from butter-milk in ten years.

From the four cows in ten years may be raised thirty calves, which sold to the butcher, when six weeks old, will have a 
value of $\$ 5.00$ each, giving for the entire lot a value of $\$ 150.00$. From this $\$ 150.00$ we must deduct the price of the milk used in rearing these calves. Assuming that each will consume two gallons of skim milk per day, equal in estimated value to four cents, we have for thirty calves, forty-two days, 2,520 gallons of milk at 2 cents per gallon, $\$ 50.40$, deducted from $\$ 150.00$ leaves $\$ 99.60$ as value of calves.

The four cows will have produced in ten years :

$9,200 \mathrm{lbs}$. of butter, at 25 cents per $1 \mathrm{~b} \ldots \ldots \ldots \ldots \ldots \ldots \ldots$

$8,8 \$ 6.36 \mathrm{lbs}$. of cheese, at 4 cents per $1 \mathrm{~b} \ldots \ldots \ldots \ldots \ldots \ldots .355$

$12,218.75$ gals. of skim milk.................... 35 . 45

373.75 gals. butter-milk, at 2 cents per gal .......... 74 75

Calf tlesh ................................... 9960

$\$ 3,18525$

Giving as the gross receipts for the four cows on ten acres for ten years $\$ 3,1 \$_{5} .25$, which is $\$ 923.25$ greater than gross receipts for wheat and $\$ 1,053.25$ greater than gross receipts for corn for the same time. This increase in the marketable produce of the two systems of farming is very apparent, while the increase of nutritive matter in the soil is no less apparent, for at the end of the decade the cropped soil will hardly produce ten bushels of wheat or twenty bushels of corn per acre, while that which has been pastured, if all the manure has been judiciously applied to the farm, has accumulated a treasure of fertilizer which may enable the farmer to harvest from 70 to So bushels of corn and from 40 to $5^{\circ}$ bushels of wheat per acre.

The amount of manure produced during these ten years is no trifling item, as its market value would almost pay each year for the winter's food. It has been asserted that the manure pile is the farmer's saving bank, and a greater truism has never been uttered. This means that if all the animal excrement were collected and properly used it would be a matter of only a few years until our farmers could live in luxury on the same land that would scarcely supply food and raiment where no attention is paid to the application of manure to the land to increase the harvest. Too much stress cannot be laid upon this. The fertilizer obtailed from the dairy herd is of far greater value 
than is commonly supposed. Of so much value has animal excrement become that in some sections men use their live stock. as machines to convert hay, straw, etc., into manure. Certainly if this is found to be a profitable business alone how much more profitable would it be should we engage in the creamery indus. try, save all the manure, apply it to our farms to enhance their value, and at the same time reap our principal harrest from the milk sold.

It is to be hoped that by a careful study of this comparison our farmers' eyes may be opened to what they can do if they would utilize nature's gifts.

\section{HOW CAN WE CONVERT OUR LANDS INTO PASTURES?}

This cannot be done at once, but the poor land of the farm by lying uncultivated while the better lands are being cropped will become covered with a sod of our natural grasses, which we claim are as fine as can be found in almost any section of these United States. Blue grass, the great pasture sod, is as luxuriant on our soil as it is in its native home, and with this. grass we are able to successfully compete with the creamery industry in other sections of the country.

Our rivers, creeks, and springs furnish an abundance of the purest water that can be found, and this, combined with our blue grass pastures, together with the grade of cattle that we already possess, is all that is necessary to make the creamery business more remunerative than any other system of farmingthat can be adopted.

Great interest has been manifested in the subject of butter and cheese manufacture wherever I have talked with the people upon this subject. There are many who are beginning to see that their cows, by grazing these steep West Virginia lands, can bring in more money each year than any other system by which these lands may be utilized. We believe that if every farmer in this State could be made to know this truth he wonld appreciate its advantages, and this prompts us to place the subject as plainly as possible before them, that each may study the comparison and decide if he will engage in a more profitable business than he now pursues. 
One other point should be observed before a decision is made. Near the larger cities, on land worth from $\$$ roo to $\$ 5$ o per acre, the creamery industry is found to pay better than any other system of farming. Why can not we with"our fine pasture lands make this our vocation?

In order that as much light as possible may be thrown "pon the subject, we give below a complete list of apparatus of a creamery for manufacturing the milk of from 100 to $200 \mathrm{cows}$, and also for a creamery with a capacity to manufacture the milk of from 200 to 500 cows-the lists difiering on account of apparatus of larger capacity being requirer in the larger creamery and extras, snch as hoisting crane, etc, being necessary in handling the larger quantities of milk.

Together with this list is a plan for a creamery building, with specifications so detailed that any ordinary carpenter can erect the building with little trouble, as all the material to be used is specified. Of course, no one is expected to be guided exclusively by these plans or specifications; they will, however, serve to give the correct idea of what is required in the construction, the structure being modified to suit the circumstances of a community. Parts of these specifications may be omitted in building, everything not being strictly necessary, and as such things. as transoms, three coats of paint, oiling on the inside, tin roofing, etc., are done away with, the cost will be materially decreased, enabling one to erect a building for from $\$ 300$ to $\$ 500$ that is in every respect suitable for carrying on the business in the most improved style.

The apparatus given in the list may be obtained from any of the frms dealing in dairy fixt.res, which are to be found throughout the country, while checks, shipping-tags, and such may beprinted at the office of your town or county paper.

It will be remembered that the prices as quoted for the differ, ent article; are taken from catalogues, and in purchasing outfit the re is always a discount of from ten to thirty per cent. allowed. This per cent. off will clecrease the cost of ontfit as given in the e stimate. 
I centrifugal cream separator ........ I churn, 300 gal ................. I engine, 6 H. P., and boiler, $S$ H. P ... I milk-testing outfit................

I butter-worker-power; hand ........ I butter print

Large Capacity. Capacity. $\$ 2 S_{5}$ oo $\$ 2 S_{5} \circ$ 30000

I set hoisting-crane fixtures..........

I pair scales -7 beam; 5 beam ........

I pair scales--platform ............

I receiving-tank-Ioo gal.; So gal .....

I milk conductor

I dipper, I gal

I graduate, $S$ oz

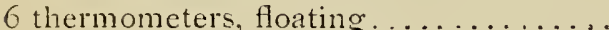

2 mops, rubber

2 vat scrub brushes

1 butter tray, 100 pounds capacity ......

I butter tray, 75 pounds capacity .....

3 butter trays, 50 pounds capacity ......

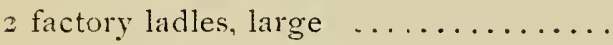

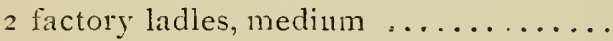

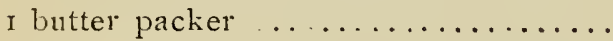

I butter spade .................

2 sieves, hair $\ldots \ldots \ldots \ldots \ldots \ldots \ldots$

I sack salt, dairy ................

I gal. butter coloring ... ...........

2 cream cans, 30 gal. capacity .........

2 cream cans, 40 gal. capacity ........

4 shipping butter boxes, 20 lbs. capacity . 4 shipping butter boxes, 40 lbs. capacity . I milk ledger ....................

I bolt butter cloth

I dozen ash tubs, 40 pounds capacity ...

I dozen ash tubs, 20 pounds capacity...

I dozen ash tubs, 60 pounds capacity ...

6 buckets, 3 gal., iron-clad...........

I gal. sperm oil 4000

I 200 5000 1000 700 30000 1200 2500 1000

$3500 \quad 3000$ $2000 \quad 2000$ r 500 I 200

I 75

75

75

60

200

So

So

350

300

750

I 00

So

75

$5^{\circ}$

I $\mathrm{OO}$

250

275

1500

IS $\infty$

1600

2000

200

So

So

300

750

I 00 So

50

I $\infty$

$25^{\circ}$

275

1500

I $S$ oo 1600 2000

75 75

500 500

336

$33^{6}$

$300 \quad 300$

$400 \quad 400$

$600 \quad 600$

200

200
4000 
I gal. machine oil...............

Large

Capacity.

$\$$ I $\infty$

35

IO 00

I 500

3000

700

600

400

700

500

500

50000
Small

Capacity.

$\$$ I 00

35

IO 00

1500

3000

700

400

700

500

500

30000

$\$ 1,4 \$ 7 \quad 46 \quad \$ 1,236 \quad 21$

The separator given in the above list is a machine which is new to many of us, and an explanation of its work will best show its use in the creamery. It consists of a steel bowl 12 inches in

*The Driving shaft in connection with Pulley.-The pulley on the shaft driving the Intermediate should be $31 / 2$ inches wide, and have crowned face. The required diameter of this pulley is ascertained as follows: Multiply the diameter of small pulley on the Intermediate ( $3 \frac{1}{2}$ inches) by the number of revolutions per minute the Intermediate ahall make (1,050 revolutions for steam power, or 975 revolutions for horse power), and divide the product by the number of revolutions the driving shaft is found to make.

The following table shows the diameter required of the driving pulley at sereral different speeds of the shaft to secure proper speed of the Separator and Intermediate for both steam and horse power:

\begin{tabular}{|c|c|c|c|c|c|c|c|c|c|c|}
\hline \multicolumn{9}{|c|}{$\begin{array}{l}\text { SPEED OF DRIVING SHAFT. } \\
\text { (Revolutions per Minute.) }\end{array}$} & \multirow{3}{*}{$\begin{array}{l}\text { SPEED OF } \\
\text { INTER- } \\
\text { MEDIATE. }\end{array}$} & \multirow{3}{*}{$\begin{array}{l}\text { SPEED OF } \\
\text { SEPA- } \\
\text { RATOR. }\end{array}$} \\
\hline 100 & 125 & 150 & 175 & 200 & 225 & 250 & \multicolumn{2}{|r|}{300} & & \\
\hline \multicolumn{9}{|c|}{$\begin{array}{l}\text { DIAMEIER OF DRIVING PULLEY } \\
\text { IN INCHES. }\end{array}$} & & \\
\hline 34 & 27 & 23 & 20 & 17 & 15 & 14 & 12 & 11 & $\begin{array}{l}975 \text { rev. per } \\
\text { min. }\end{array}$ & 7,500 rev. per \\
\hline 37 & 20 & 25 & 21 & 18 & 16 & 15 & 14 & 12 & $\begin{array}{l}1050 \text { rev. per } \\
\text { mill. }\end{array}$ & $\begin{array}{l}6,000 \text { rev per } \\
\text { min. }\end{array}$ \\
\hline
\end{tabular}


dianeter, having connected with it on the under siche a spmdle I 5 inches long; which fits into a cup-like piece of steel. This spindle of the bowl is connecterl with the engine by means of a system of pulleys and belts so that a relocity of 6,500 revolutions per minute is obtained. The warm milk is made to flow into the bowl through the opening in the top when the bowl has acquired the required number of revolutions. The rapid revolution of the separator throws the cream to the center of the bowl, while the milk is walled up against the inside. Proper outlets are provided by which the cream and milk pass out in separate streams to pans provided with spouts, which convey the cream to one vessel and the skim milk to the other. The principle on which the machine works is not new, as it is centrifugal force, but this application of it to separating cream from milk is recent.

By the use of this machine the milk may be freed of its cream at the rate of 100 gallons per hour, leaving both cream and skim milk in a perfectly sweet condition.

This process enables the cream to be taken from the milk immediately, without having to wait from 12 to 36 hours, as is necessary with any other system. The slim milk, being destitute of all cream, is either taken home (the cream only being left at the creamery) and there utilized to the best advantage or left at the creamery to be converted either into cheese or pork.

A system of ehecks is used at the creamery, which enables both patron and creamery man to keep a correct accumt of the number of pounds of milk delivereu. The check is perfurated across the center, the upper and lower sides being filled out in exactly the same manner. For instance, the check represents A. B. as having delivered on the morning of January Ist, ISS9, $35^{\circ}$ pounds of milk. The check is torn in two at the centerone half being given to the patron, while the other is filed at the creamery for roference. 


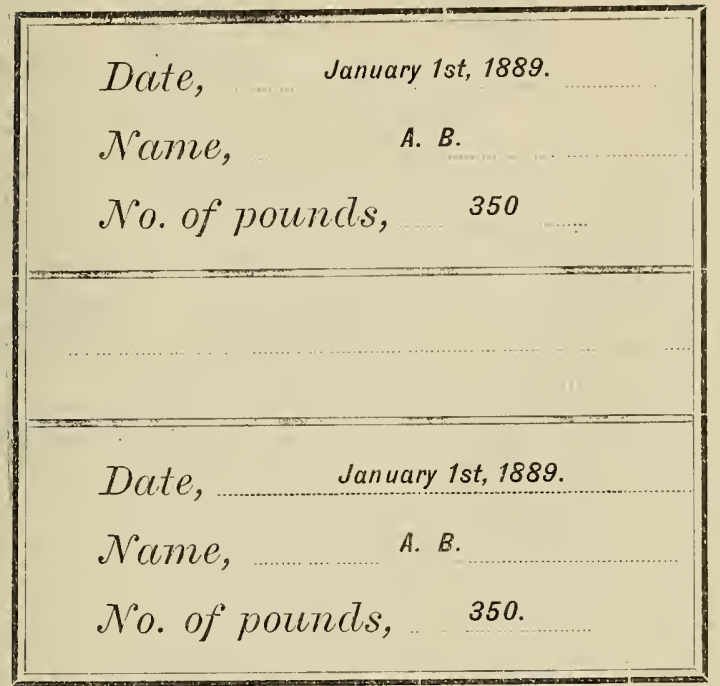

Of course the milk ledger, which is properly ruled, contains the number of pounds of milk delivered by each patron each day. At the end of the month the patrons add the number of pounds on their checks to see that no mistake is made at the creamery. This system has been adopted as the best means of keeping accurately each man's account.

The shipping tag, to which we alluded in the foregoing list, is only for butter boxes, etc., which are shipped to the markets. It is arranged as follows:

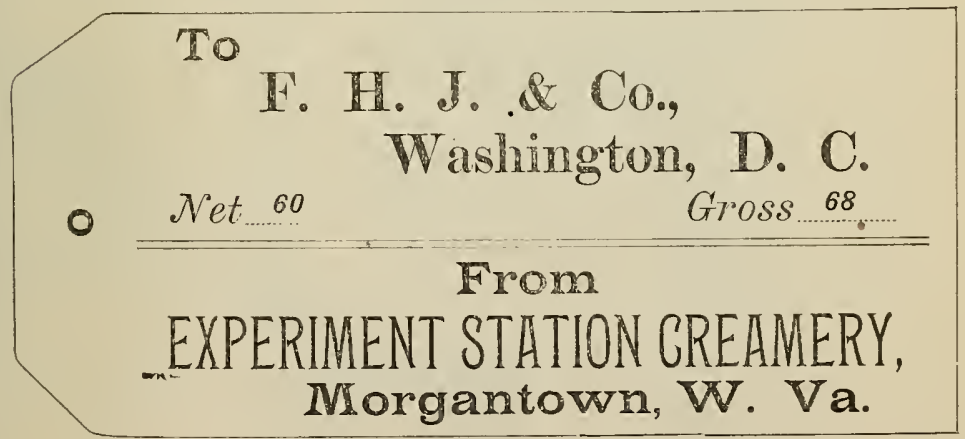

The cuts on following page give both front and side elevation of building: specifications which follow will guide as to dimensions. 

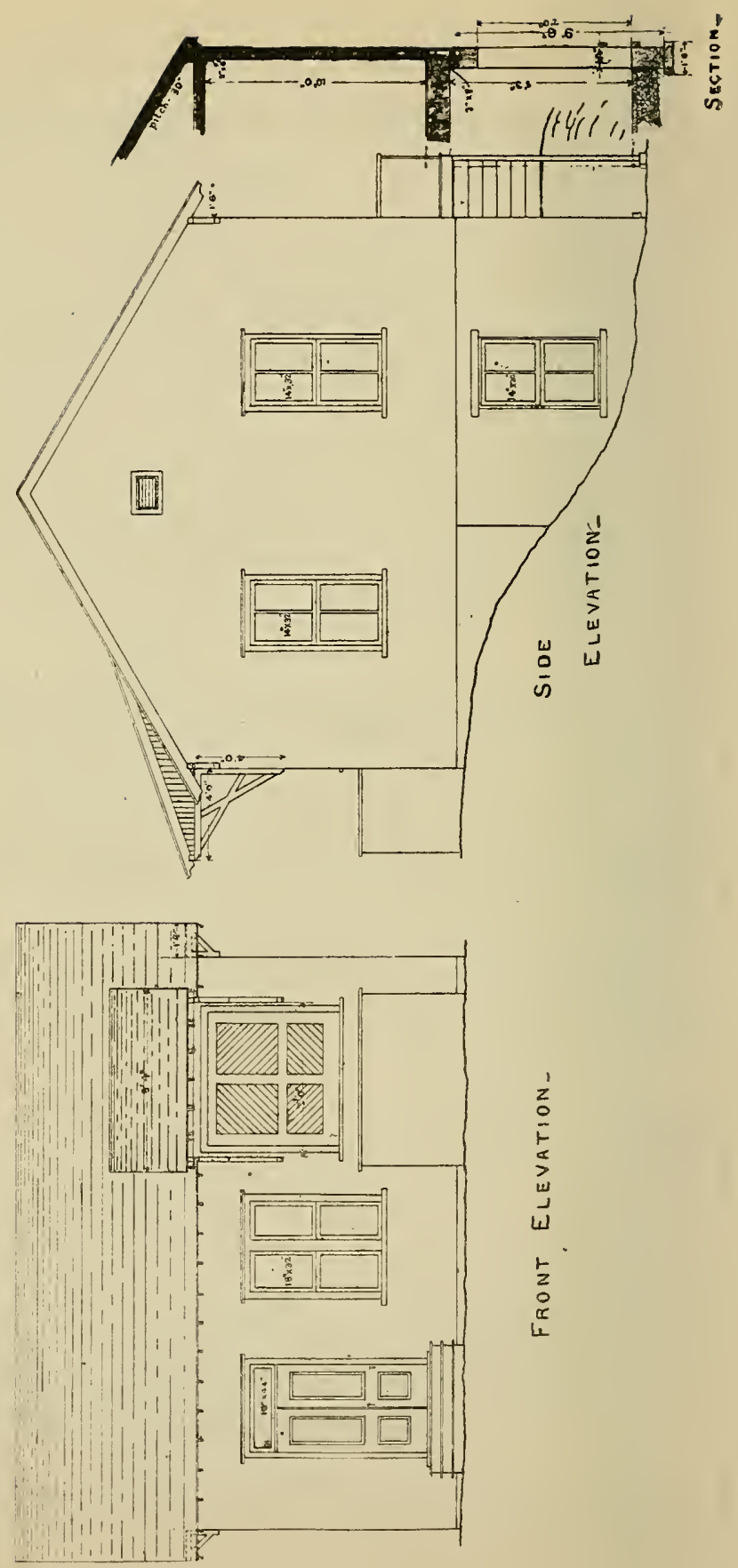

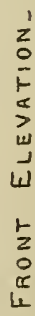



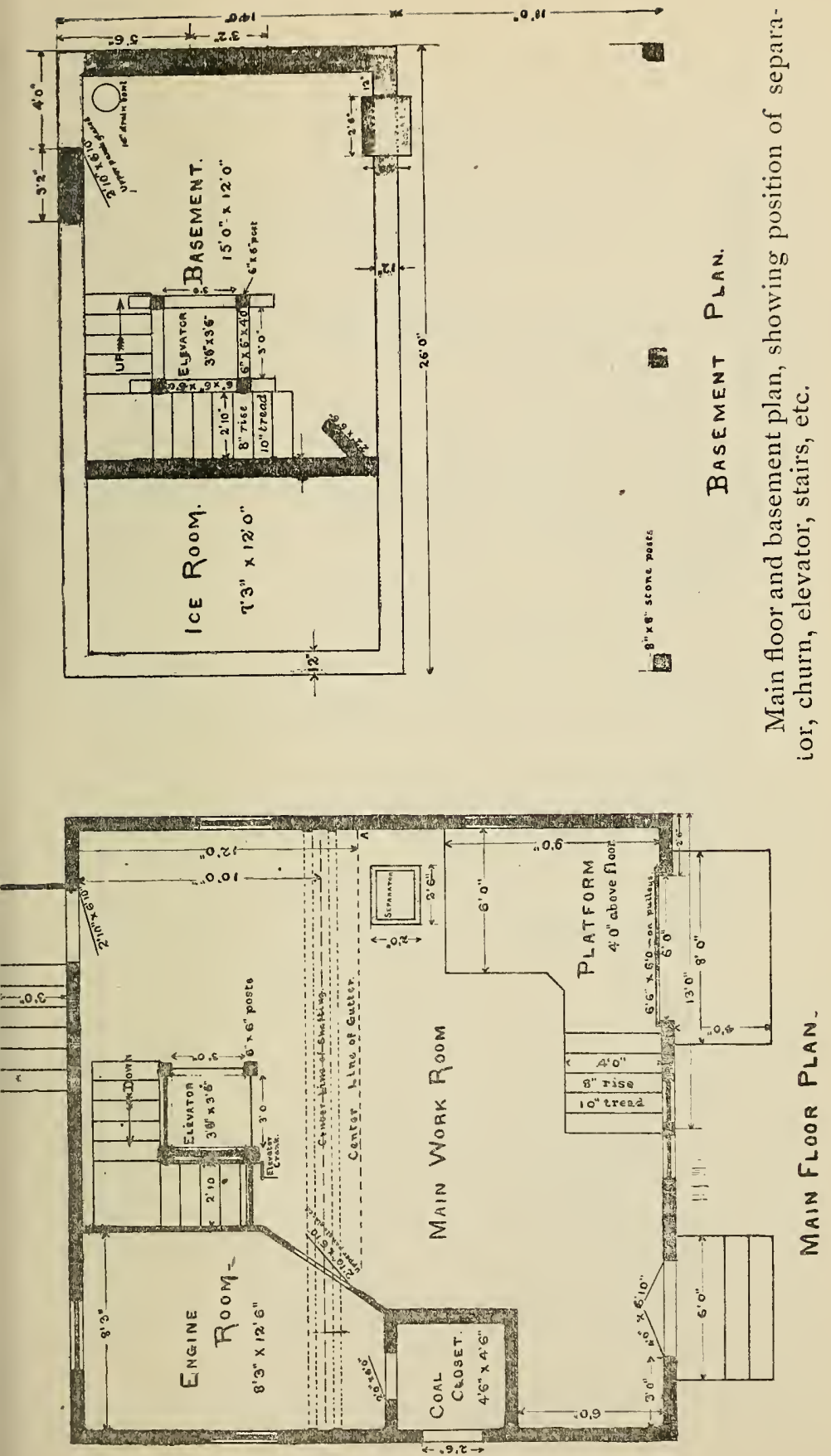


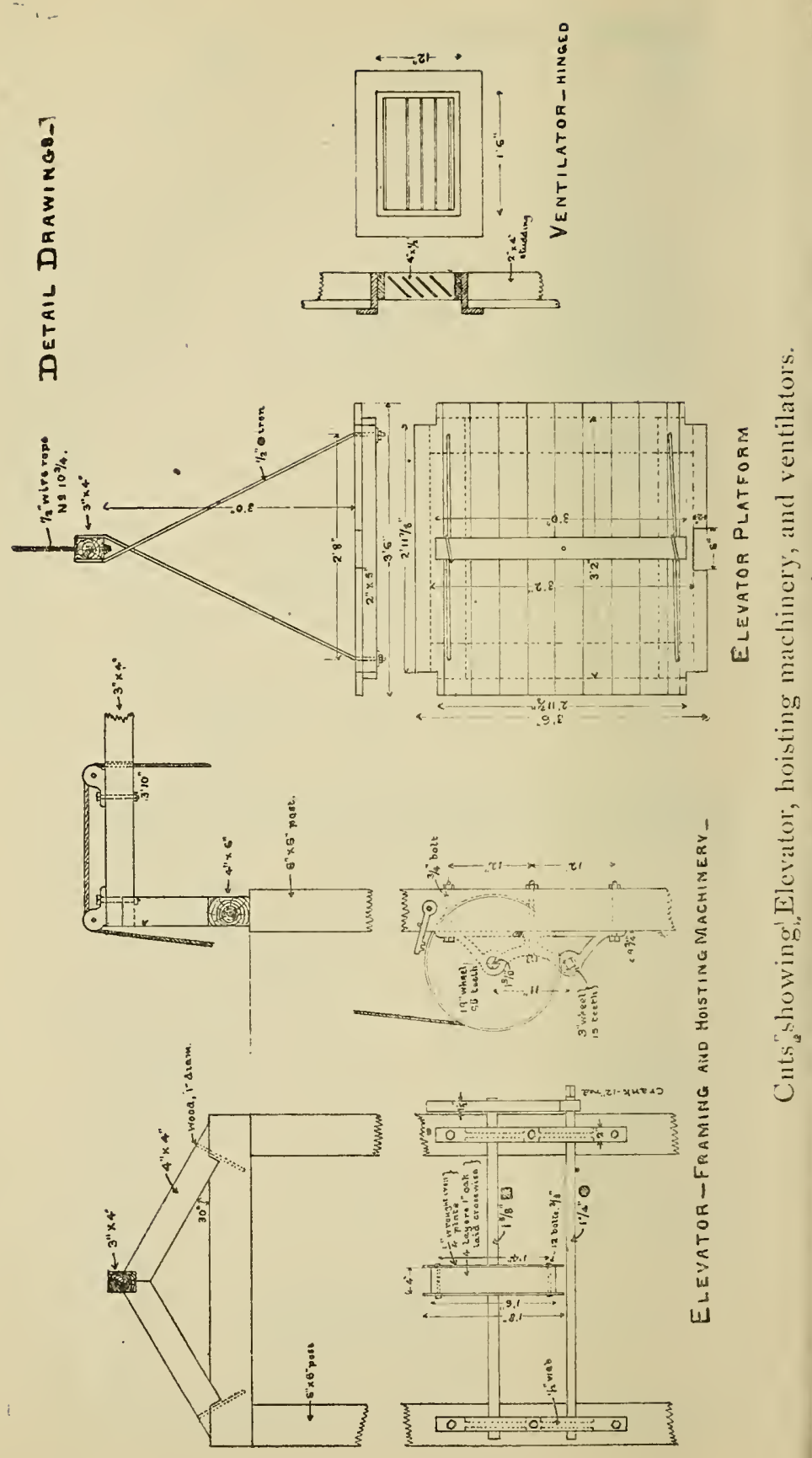




\section{SPECIFICATIONS.}

GENERAI.

These plans and specifications are supplementary, and anything drawn or described in either will be considered as part of the contract. Written dimensions will govern measurements on plans, but measurements may be taken provided the required dimensions are not given in either plans or specifications. All workmanship must be perfect and the materials first class of their kinds as specified.

\section{EXCAVATION.}

Excavate under the basement to $9^{\prime} 3^{\prime \prime}$ under required level of top of foundation wall-to ro feet, under walls of basement. No excavation under front of building, except for foundation stones, which shall be $S^{\prime \prime}$ square and long enough to be sunk $2^{\prime} 6^{\prime \prime}$ under ground. All these foundations shall be constructed even deeper than here specified should the nature of the soil at these depths prove too insecure for a firm foundation. A 3 -inch tile drain with fall of $\mathrm{r}$ inch in 50 shall be laid from the bottom of the basement to a point where it shall have free out-flow.

\section{MASONRY.}

A footing course $r S^{\prime \prime}$ wide and at least $4^{\prime \prime}$ thick shall be laid under all masonry walls. The walls shail be stone rubble, r $2^{\prime \prime}$ thick, laid in a mortar composed of I part freshly burnt lime, I part hydraulic cement and 8 parts of clean sharp sand. The 9inch partition wall between the ice room and hasement shall be of brick. The bottom of the ice room and basement shall have a layer of small stones and gravel $\mathrm{I} 2$ " thick. the stones being placed on the bottom. This shall be overlaid with a $3^{\prime \prime}$ layer of concrete composed of I part hydraulic cement and 3 parts sand, the floor surface being dressed ofl smooth. The basement floor shall slope toward the comer where the drain bowl is, where the floor shall be 3 " lower than the opposite diagonal corner of 
the basement. The floor of the ice room shall slope toward the door.

The foundation for the "Separator" shall be a single stone 2 ' $0^{\prime \prime} \times 2^{\prime} 6^{\prime \prime} \times o^{\prime} S^{\prime \prime}$. The sides of this stone projecting over the I $2^{\prime \prime}$ wall to be braced by corbels built into the wall immediately underneath. This stone (perfectly level on top) to be at height of main floor.

The walls of the ice room and basement to be plastered directly on the masonry; two coat work; both coats containing ro\% cement.

\section{CARPENTRY-FRAMING.}

All framing to be of poplar or hemlock, except as particularly specifiel. Sills, under front part, $6^{\prime \prime} \times \mathrm{S}^{\prime \prime}$; under back part, $3^{\prime \prime}$ $\mathrm{x} S^{\prime \prime}$. Studding, $2^{\prime \prime} \times 4^{\prime \prime}$. Corner posts, $4^{\prime \prime} \times 4^{\prime \prime}$. Plates, 2 pieces, $2^{\prime \prime} \times 4^{\prime \prime}$. Girts, oak, I" $\times 6^{\prime \prime}$. Floor joists for main floor, oak, $2^{\prime \prime} \times 12^{\prime \prime}$ spaced $\mathrm{I} S^{\prime \prime}$ on centers. Ceiling rafters, $2^{\prime \prime} \times 5^{\prime \prime}$, spaced $16^{\prime \prime}$ on centers. Roof rafters, $2^{\prime \prime} \times 5^{\prime \prime}$, spaced $16^{\prime \prime}$ on centers.

\section{FLOORING.}

The joists under the engine and engine room to be doubled. The floor to be sloped from front and back toward the gutter through the center of the building. The gutter at A (see Main Floor Plan) to be $4^{\prime \prime}$ lower than the fioor level at front and back and $2^{\prime \prime}$ lower than the other end of the gutter. The floor to be laid with $\frac{\gamma^{\prime \prime}}{8}$ oak, matched and dressed. The attic floor to be covered with rough hemlock or poplar boarding $I^{\prime \prime}$ thick for a width of ro feet under the ridge of the roof. Joists doubled under "Intermediate" (directly back of "Separator").

\section{SID I NG.}

The outside walls to be covered with $\frac{\tau^{\prime \prime}}{5}$ poplar siding. The outside corners to be cased with $4^{\prime \prime}$ poplar casing and a $6^{\prime \prime}$ plancher shall be placed under the eares front and back.

\section{CEILING AND INSIDE WALLS.}

The ceiling and insicle walls shall be ceiled with narrow, beaded, tongued and grooved, $\frac{5}{3}$ " poplar, not more than $3^{\prime \prime}$ 
wide. The walls of the coal room to have only rough poplar or bemlock boards, $I^{\prime \prime}$ thick, nailed to the studding to height of 6 feet above the floor. The partition between the engineroom and main work-room to be made by laying ceiling stuff on a frame-work of dressed poplar made of $x^{\prime \prime} \times 3^{\prime \prime}$ stuff into panels about 3 feet square. All corners between floor and walls, between adjacent walls and between walls and ceiling to be filled with quarter-round $\mathrm{I}^{\prime \prime}$ nosing.

DOORS.

All doors except the two doors in the front to be $\mathrm{I} \frac{3^{\prime \prime}}{8}$, flat-panel doors of sizes as shown on plans. The main front door to be donble-I $\frac{3{ }^{\prime \prime}}{t}$ thick--panels moulded on the outside-transom above. The sliding door on platform to be made of design as shown on front elevation; its framing $\mathrm{I} \frac{z^{\prime \prime}}{4}$ thick, the paneling $\frac{7}{8}$ thick, sunk into framing so as to be flush on the inside; to be hung on pulleys running on rail overhead; to have a hook and staple for fastening it closed. All swinging doors to be provided with hinges, key locks and bronze knobs, two of them (as indicated on plans) having the upper panels glazed.

The door to the ice room to be $6^{\prime \prime}$ thick, made by securing to an ordinary door a box filled with perfectly dry sawdust, the door itself forming one face of the box. The box to be made of $\mathrm{I}^{\prime \prime}$ dressed poplar. The top, bottom, and handle side of the door to be beveled so as to swing into its frame easily, which is to be beveled correspondingly. This door to be swung on three heavy 6-inch strap hinges and to be provided with a bolt for fastening it when closed. A simple handle for pulling the door open shall also be provided.

All door and window frames shall be cased both insicle and outside.

\section{WIN DOWS.}

Glass of sizes as shown on plans, and sashes and frames to correspond. Windows to be hung with weights and pulleys and provided with proper fastenings. The large double window in front is really two single independent windows placed so as to allow just room enough for the weight boxes between them. The window to the coal room $\left(2^{\prime} 6^{\prime \prime}\right.$ wide and $2^{\prime} o^{\prime \prime}$ 
high, its sill 5' $\mathrm{o}^{\prime \prime}$ above the floor) to be closed by a shutter, swinging in and hung at the top, provided with hinges, a bolt to fasten it when closed and a hook to keep it open.

There shall be a ventilator (see detail drawings) in each gable end, ${ }^{2} S^{\prime \prime}$ wide and $\mathrm{I} \mathbf{2}^{\prime \prime}$ high, made by placing within simple box frame horizontal slats $4^{\prime \prime}$ wide. $\frac{1}{2}$ " thick, placed $2^{\prime \prime}$ apart, and sloping outward and at an angle of $45^{\circ}$. This box frame shall be hung on hinges at the side, and so made (slightly beveled at the side) that it may be swung open. To be provided with a hook to fasten it when closed.

ROOF.

The first two pairs of rafters at each end shall be exposed underneath, also the overhanging ends of all the others. The first pair of rafters at exch are supported by a pair of brackets i $S^{\prime \prime}$ $\mathrm{x} I S^{\prime \prime}$ made (as shown on front elevation) of $3^{\prime \prime} \times 3^{\prime \prime}$ poplar. The projecting roof over the platform shall be supported by two brackets $4^{\prime} \mathrm{O}^{\prime \prime} \mathrm{x} 4^{\prime} \mathrm{O}^{\prime \prime}$ made (as shown in side eleration) of $4^{\prime \prime} \times 4^{\prime \prime}$ poplar, and placed $7^{\prime} \mathrm{O}^{\prime \prime}$ apart, on each side of the doorway. The rafters of this projecting roof shall be supported (on the front end) by a piece of poplar $4^{\prime \prime} \times 4^{\prime \prime} x S^{\prime} O^{\prime \prime}$, which shall rest on the front ends of the two large brackets. The two end rafters of this projecting roof shall be $4^{\prime \prime} \times 5^{\prime \prime}$ section and shall rest directly above the brackets, the other five being spaced equally between these two. The rafters on the main roof corresponding to these shall be directly underneath them and shall not overhang the wall line. The second rafter from each end of the main roof shall be close against the end walls (taking the place of a plancher). Between the rafter at the right end of the building and the one at the right end of the projecting roof there shall be 2 rafters equally spaced-the interval from center to center will be about $15 \frac{1}{3}$ inches. At the left end of the building, there shall be one rafter between the one at the wall line and the end rafter of the projecting roof. The extreme end rafters shall have the same interval ( $15 \frac{1}{3}$ inches) from the rafters at the wall line. The roof shali be sheathed with $\frac{t^{\prime \prime}}{8}$ poplar sheathing. All exposed wood-work (the overhanging ends of the rafters, the two rairs of rafte:s at each end and the slaathing under the eaves) shall be dressed smooth. 
Tine uncler side of the platform roof shall be ceiled with $5^{5}$ " narrow, beaded, tongued and grooved poplar, just above the level of the brackets. The space between the brackets and the rafters immediately above them (see side elevation) shall be filled with the same ceiling material.

\section{STAIRS.}

All stairs and steps to be built with $S^{\prime \prime}$ rise and $\mathrm{O}^{\prime \prime}$ tread. Stringers, treach and risers of oak. Treads, $I^{\prime \prime}{ }^{\prime \prime}$ thick ; risers, $\frac{7^{\prime \prime}}{8}$ thick ; stringers, $I_{4}{ }^{\prime \prime}$ thick. The front steps to be trimmed and cased with poplar. A plain guard rail, $2^{\prime \prime} \times 4^{\prime \prime}$, with plain supports, shall be provicled for the back steps. A plain poplar guard rail shall also be placed between the posts of the elevator where adjacent to the main stairs. The stringers of the main stairs next to the elevator may be supported by securing them to the elevator posts.

\section{PLATFORMS.}

Both inside and outsicle platforms to be built of $2^{\prime \prime} \times 5^{\prime \prime}$ joists resting on $3^{\prime \prime} \times 6^{\prime \prime}$ girders on the outside end and on $x^{\prime \prime} \times 6^{\prime \prime}$ girts nailed to the studding on the wall end. The girders shall be supported by $4^{\prime \prime} \times 4^{\prime \prime}$ posts placed at the corners. The flooring of platforms same as that of main floor. The inside platform to be cased with $\frac{5^{\prime \prime}}{8}$ poplar ceiling stuff. The outside platform to be cased with $x^{\prime \prime}$ poplar.

\section{ELEVATOR.}

Its foundation shall consist of two pieces $6^{\prime \prime} \times 6^{\prime \prime} \times 6^{\prime} 0^{\prime \prime}$ resting on the concrete floor and made perfectly level. Resting on these, at right angles to them and connecting them, shall be two pieces $6^{\prime \prime} \times 6^{\prime \prime} \times 4^{\prime} \mathrm{O}^{\prime \prime}$. The posts resting on this foundation shall be $6^{\prime \prime} \times 6^{\prime \prime} \times 2 \mathrm{I}^{\prime} \mathrm{O}^{\prime \prime}$ extending about 2 feet above the attic floor. At the tops there shall be a pair of trusses (see detail drawings) connected by a piece $3^{\prime \prime} \times 4^{\prime \prime} \mathrm{x}$ $4^{\prime} \mathrm{O}^{\prime \prime}$. The trusses run front and back as to the building. All this framing of oak. The floor joists and ceiling rafters to be secured to this framing so that they will be mutually braced.

The wire rope from elevator platform shall come up through the cross piece at its middle, over an iron pulley placed there then to end of cross-piece, over another pulley there, and then 
down outside the elevator to a drum revolving with an axle whose bearings are secured to two of the elevator posts. The axle to be provided with crank, ratchet and pawl.

The elevator platform to be built of floor boarding screwed to a framing of $2^{\prime \prime} \times 5^{\prime \prime}$ oak. The platform to have at each end a hanger of $\frac{1}{2}^{\prime \prime}$ round iron. These hangers to be connected at top by a cross-piece $\left(3^{\prime \prime} \times 4^{\prime \prime} \times 3^{\prime} \mathrm{O}^{\prime \prime}\right)$ to the center of which is fastened the wire rope, which shall be $\frac{1}{2}^{\prime \prime}$ diameter. The corners of the elevator platform $\left(3^{\prime} 6^{\prime \prime} \times 3^{\prime} 6^{\prime \prime}\right)$ shall be notched so as to slide between the elevator posts as guides.

\section{FRAMING FOR SHAFTING.}

In the side walls of the main floor at each end of the line of shafting, there shall be two oak posts built into the wall, each $4^{\prime \prime} \times 6^{\prime \prime}$ section, the $6^{\prime \prime}$ side at right angles to the wall. Resting on these and immediately under the ceiling rafters there shali be two oak girders $4^{\prime \prime} \times 6^{\prime \prime}$ (the $6^{\prime \prime}$ side vertical), the pulley hangers being secured to these girders. These girders shall be 12 " between centers.

CHURN POSTS.

There shall be two vertical oak posts, $t^{\prime \prime} \times 6^{\prime \prime}$, extending from floor to ceiling and properly securedl, placed wherever it may be directed, to which the revolving churn shall be hung.

TINNING.

The roof shall be timned with charcoal tin, standing joints. Gutters and leaders shall be provided for the eaves on the rear and the eaves on the front above the front door and window.

The gutter on the floor of the main work-room shall have a galvanized iron lining extending 12 inches each side of the center line of the gutter. The edges shall be tacked very closely and tightly and then made water-tight with oil and putty. At the lower end of the gutter (at A on the plan) a 3-inch tin pipe shall be let through the wall and continued down the outside to the ground where it will empty into a $3-$ inch tile drain pipe (which also connects with the drain bowl in basement) which will be run out to some point at least 25 feet from the building, where it shall have free out-flow. The 
inside of the wall shall be flashed for $6^{\prime \prime}$ around this outlet pipe with tin.

A sheet of heavy galvanized iron, $5^{\prime} \mathrm{O}^{\prime \prime} \times 6^{\prime} \mathrm{O}^{\prime \prime}$, shall be placed under and in front of the fire-box of the engine.

The sheet-iron smoke-stack of the engine shall be carried straight up through the ceiling and roof, which must be cut out so that no wood-work sha 1 be closer than $3^{\prime \prime}$ to the stack.

The anular openings thus made shall be filled with sheetiron. The stack is to be surmounted by a sheet-iron cap.

PAINTING, OILING, \&C.

All the outside wood-work shall be painted three coats good quality lead paint in any three colors that may be selected. All knots to be filled with shellac before painting. The roof shall be painted on both sides with mineral paint.

All the inside wood-work, except in the attic and coal room, to be oiled with two coats of boiled linseed oil.

\section{SEPARATOR.}

The foundation stone of the separator shall have bolt holes bored through it at places corresponding to the holes in the iron base of the machine. The bolts, with their heads at the under side of the stone, shall he placed in position when the stone is set.

\section{ENGINE AND BOILER.}

The engine and boiler had best be of the horizontal type, six-horse power, with the engine placed on top of the boiler.

\section{BILL OF MATERIALS.}

The following bill of materials has been made out witk special reference to the erection of this building at a proposed site at Morgantown, W. Va. Note will be made, however, of the changes necessitated in this bill in order to adapt it to any locality. A mark will be made against each item whose amount varies with the locality. 
MASONRY, EXCAVATION, \&C.

$25.6 \mathrm{cu}$. yds. stone rubble, $12^{\prime \prime}$ thick.

87 lin. ft. footings, $\mathrm{r}^{\prime} 6^{\prime \prime}$ wide, at least $4^{\prime \prime}$ thick ... $2 \frac{3}{4} \mathrm{cu} . \mathrm{yds}$. brick, (in $9^{\prime \prime}$ partition wall)... .....

I door cap, I window cap and sill, each $4^{\prime \prime} \times 12^{\prime \prime}$ $\mathrm{x} t^{\prime} \mathrm{o}^{\prime \prime}$.

I door sill. $S^{\prime \prime} \times 12^{\prime \prime} \times 4^{\prime} O^{\prime \prime} \ldots$

3 foundation stones, $S^{\prime \prime} \times S^{\prime \prime} \times 3^{\prime} O^{\prime \prime}$ (sometimes longer) ..

I stone, $2^{\prime} O^{\prime \prime} \times 2^{\prime} 6^{\prime \prime} \times o^{\prime} S^{\prime \prime}$ (foundation for separator).......

Tile drain, $3^{\prime \prime}$ diam., (length variable)...

Excavation, about $60 \mathrm{cu}$. yds. at University, maximum about i $10 \mathrm{cu}, y \mathrm{ds}$.

$10.3 \mathrm{cu}$. yds sand and coarse gravel for basement floor

$2.6 \mathrm{cu}$. yds. concrete for basement floor...

79 sq. yds. plastering, 2 coat work

1 drain bowl, r4" diam., set in basement. .

LUMBER.

ft. b. m.

2 sills, $3^{\prime \prime} \times S^{\prime \prime} \times 26^{\prime} o^{\prime \prime} \ldots \ldots \ldots \ldots \ldots \ldots . \quad 52$

2 " $\quad \times 25^{\prime} \mathrm{O}^{\prime \prime} \ldots \ldots \ldots \ldots \ldots \ldots \ldots \ldots$

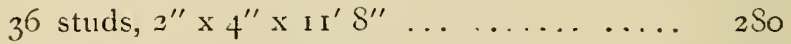

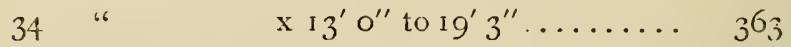

$9 \quad$ " $9 \mathrm{IO}^{\prime} \mathrm{O}^{\prime \prime} \ldots \ldots \ldots \ldots \ldots .60$

4 corner posts, $4^{\prime \prime} \times 4^{\prime \prime} \times$ i I' $8^{\prime \prime} \ldots \ldots \ldots \ldots .62$

4 plates, $2^{\prime \prime} \times 4^{\prime \prime} \times 26^{\prime} \mathrm{O}^{\prime \prime} \ldots \ldots \ldots \ldots \ldots \ldots .69$

20 ceiling rafters, $2^{\prime \prime} \times 5^{\prime \prime} \times 25^{\prime} \mathrm{O}^{\prime \prime} \ldots \ldots \ldots .4 \mathrm{4} 7$

41 roof $" x 16^{\prime} 3^{\prime \prime} \ldots \ldots \ldots .555$

7 " $7 \quad \times 14^{\prime} 9^{\prime \prime} \ldots \ldots \ldots$ S6

5 " " $\quad$ " $\quad$ " $10^{\prime} 6 " \ldots \ldots \ldots .44$

2 " " 4 " $\times 55^{\prime \prime} \times 10^{\prime} 6^{\prime \prime} \ldots \ldots \ldots . \quad \mathrm{I}_{7}$

I beam, $4^{\prime \prime} \times 4^{\prime \prime} \times S^{\prime} O^{\prime \prime}$ (on front brackets). I I

Poplar lumber................. 2,066

19 joists, $2^{\prime \prime} \times 12^{\prime \prime} \times 13^{\prime} 6^{\prime \prime} \ldots \ldots \ldots \ldots \ldots \ldots .513$ 
4 joists $2^{\prime \prime} \times 12^{\prime \prime} \times 6^{\prime} 0^{\prime \prime} \ldots \ldots \ldots \ldots \ldots \ldots \ldots 4^{S}$

$2 \quad$ " $\quad \times 6^{\prime} 6^{\prime \prime} \ldots \ldots \ldots \ldots \ldots \ldots 26$

2 girts, $I^{\prime \prime} \times 6^{\prime \prime} \times 25^{\prime} O^{\prime \prime} \ldots \ldots \ldots \ldots \ldots \ldots .25$

2 " $\quad \times 24^{\prime} 0^{\prime \prime} \ldots \ldots \ldots \ldots \ldots \ldots .24$

I " $\quad \mathrm{x} \mathrm{S}^{\prime} 6^{\prime \prime} \ldots \ldots \ldots \ldots \ldots \ldots \ldots, 4$

I " $\quad x 9^{\prime} \mathrm{O}^{\prime \prime} \ldots \ldots \ldots \ldots \ldots \ldots \ldots$

I " $\quad x 7^{\prime} S^{\prime \prime} \ldots \ldots \ldots \ldots \ldots \ldots, 4$

In side platform-

6 joists, $2^{\prime \prime} \times 5^{\prime \prime \prime} \times 3^{\prime}{ }^{10} 0^{\prime \prime} \ldots \ldots \ldots \ldots \ldots \ldots$

5 “ $\quad x 5^{\prime}{ }^{1 \prime \prime} \ldots \ldots \ldots \ldots \ldots \ldots .24$

1 girder, $3^{\prime \prime} \times 6^{\prime \prime} \times S^{\prime} 6^{\prime \prime} \ldots \ldots \ldots \ldots \ldots \ldots \ldots$

I " $\quad \mathrm{x} 5^{\prime} \mathrm{O}^{\prime \prime} \ldots \ldots \ldots \ldots \ldots \ldots$

3 posts, $4^{\prime \prime} \times 4^{\prime \prime} \times 3^{\prime} o^{\prime \prime} \ldots \ldots \ldots \ldots \ldots \ldots \ldots$

Outside platform-

7 joists, $2^{\prime \prime} \times 5^{\prime \prime} \times 3^{\prime} 9^{\prime \prime} \ldots \ldots \ldots \ldots \ldots \ldots$

I girder, $3^{\prime \prime} \times 6^{\prime \prime} \times 7^{\prime} S^{\prime \prime} \ldots \ldots \ldots \ldots \ldots \ldots$ 12

2 posts, $4^{\prime \prime} \times 4^{\prime \prime} \times 3^{\prime} 6^{\prime \prime} \ldots \ldots \ldots \ldots \ldots \ldots \ldots$

\section{Elevator-}

2 sills, $6^{\prime \prime} \times 6^{\prime \prime} \times 6^{\prime} o^{\prime \prime} \ldots \ldots \ldots \ldots \ldots \ldots \ldots .36$

2 " $\quad \times 4^{\prime} o^{\prime \prime} \ldots \ldots \ldots \ldots \ldots \ldots \ldots . \ldots \ldots$

4 posts, $6^{\prime \prime} \times 6^{\prime \prime} \times 2 \mathrm{r}^{\prime} \mathrm{o}^{\prime \prime} \ldots \ldots \ldots \ldots \ldots \ldots \ldots$

2 beams, $4^{\prime \prime} \times 6^{\prime \prime} \times 4^{\prime} \mathrm{O}^{\prime \prime} \ldots \ldots \ldots \ldots \ldots \ldots$

4 " $\quad 4^{\prime \prime} \times 4^{\prime \prime} \times 2^{\prime} 0^{\prime \prime} \ldots \ldots \ldots \ldots \ldots \ldots$ I I

I “ $\quad 3^{\prime \prime} \times 4^{\prime \prime} \times 4^{\prime} \mathrm{O}^{\prime \prime} \ldots \ldots \ldots \ldots \ldots \ldots \ldots$

I " $\quad \times 3^{\prime} 0^{\prime \prime} \ldots \ldots \ldots \ldots \ldots \ldots$

\section{Shafting-}

4 posts, $6^{\prime \prime} \times 4^{\prime \prime} \times$ IO $^{\prime} 7 \frac{1^{\prime \prime}}{2} \ldots \ldots \ldots \ldots \ldots \ldots \ldots S_{5}$

2 girders, $25^{\prime}$ IO $^{\prime \prime} \ldots \ldots \ldots \ldots \ldots \ldots \ldots \ldots \ldots$ 10.3

Churn posts-

2 posts, $6^{\prime \prime} \times 4^{\prime \prime} \times 10^{\prime} o^{\prime \prime} \ldots \ldots \ldots \ldots \ldots \ldots$. 40

Oak lumber ................. I,S62

2 brackets, $1^{\prime} 6^{\prime \prime} \times r^{\prime} 6^{\prime \prime}$, made of $3^{\prime \prime} \times 3^{\prime \prime}$ poplar (see front elevation).

2 brackets, $4^{\prime} \mathrm{O}^{\prime \prime} \times 4^{\prime} \mathrm{O}^{\prime \prime}$, made of $4^{\prime \prime} \times 4^{\prime \prime}$ poplar (see side elevation)

672 f.. h, m. flooring, $\frac{\tau^{\prime \prime}}{8}$ oak (including both platforms) 


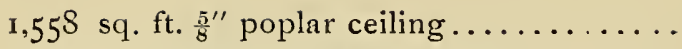

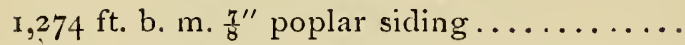
$993 \mathrm{ft}$. b. m. sheathing for roof ( $\frac{\tau^{\prime \prime}}{8}$ poplar).. $25^{2}$ lin. ft. I inch quarter-round nosing..... Ix 6 lin $\mathrm{ft}$. $\mathrm{I}^{\prime \prime} \times 3^{\prime \prime}$ poplar for partition of en-

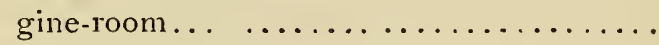

I 7 lin. ft. poplar for guard-rail, $2^{\prime \prime} \times 3^{\prime \prime}$, main

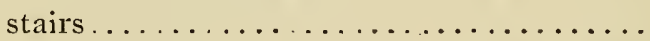

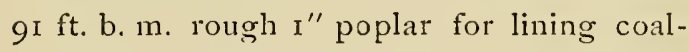
room.

$23 \mathrm{ft}$. b. m. oak in elevator platform.......

\section{DOORS}

(with frames and casings.)

I pair doors, $4^{\prime} \mathrm{O}^{\prime \prime} \times 6^{\prime} \mathrm{IO}^{\prime \prime} \times \mathrm{I} \frac{z^{\prime \prime}}{4}$. with $\mathrm{I} 4$ transom

I sliding door, $6^{\prime} 6^{\prime \prime} \times 6^{\prime} \mathrm{o}^{\prime \prime}$.

2 doors, $2^{\prime} \mathrm{IO}^{\prime \prime} \times 6^{\prime} \mathrm{IO}^{\prime \prime} \times \mathrm{I} \frac{3^{\prime \prime}}{8}$, O. G. flat-panel,

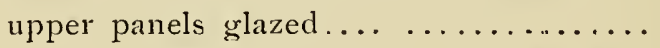

I door, $2^{\prime} 1^{\prime \prime} \times 6^{\prime} 1^{\prime \prime} \times 1 \frac{3^{\prime \prime}}{8}$ O. G. flat-panel I “ $2^{\prime} \mathrm{O}^{\prime \prime} \times 6^{\prime} \mathrm{O}^{\prime \prime} \times \mathrm{I} \frac{3^{\prime \prime}}{8}$,

I “ $2^{\prime} 2^{\prime \prime} \times 6^{\prime} 6^{\prime \prime} \times 1 \frac{3^{\prime \prime}}{8}$, O. G. flat-panel for ice-room. About $3^{2} \mathrm{ft}$. b. m. of $\mathrm{I}^{\prime \prime}$ poplar will be required for the completion of this door and its frame..............

I shutter to coal-room, $2^{\prime} 6^{\prime \prime}$ wide, $2^{\prime} \mathrm{o}^{\prime \prime}$ high, swung at top, requiring about $S$ ft. b. m..

\section{WINDOWS}

(with frames and casings.)

4 windows, 4 panes, $14^{\prime \prime} \times 32^{\prime \prime}$, weights and pulleys...................

I window, 4 panes, 14 " $\times 2 S^{\prime \prime}$, weights and

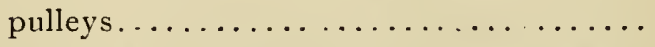

2 windows, 4 panes, I $S^{\prime \prime} \times 32^{\prime \prime}$, weights and

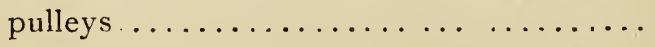

2 ventilator windows, $\mathrm{I}^{\prime \prime} \mathrm{X} \mathrm{IS}^{\prime \prime}$ (as per specifications and detailed drawings) ....... 
Main stairs-

STAIRS AND STEPS.

ft. b. m.

12 treads, $2^{\prime} \mathrm{IO}^{\prime \prime} \times \mathrm{O}^{\prime} \mathrm{II} \mathrm{I}^{\prime \prime} \mathrm{x} \mathrm{I}_{8}^{\prime \prime} \ldots \ldots \ldots \ldots \ldots 35$

I4 risers, $2^{\prime} \mathrm{I}^{\prime \prime} \mathrm{x} \mathrm{O}^{\prime} S^{\prime \prime} \mathrm{x} \frac{7^{\prime \prime}}{8} \ldots \ldots \ldots \ldots \ldots \ldots . . \ldots 23$

I platform, $2^{\prime} \mathrm{IO}^{\prime \prime} \times 2^{\prime} \mathrm{IO}^{\prime \prime} \times \mathrm{I} \mathrm{y}_{\mathrm{g}}^{\prime \prime} \ldots \ldots \ldots \ldots . .99$

Stringers, $I \frac{1}{2}{ }^{\prime \prime}$ thick, 3 rows............ 60

Framing to support stair platform, $2^{\prime \prime} \times 6^{\prime \prime}$. I6

I 43

Front steps................ (abont) So

Poplar casing for outside platform. " " 72

Steps to inside platform......... " 68

Back steps (variable according to locality )..................... (about) 70

TINNING.

9.93 sq. of tinning

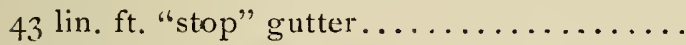

37 lin. ft. $3^{\prime \prime}$ leaders

${ }_{3} 8 \mathrm{sq}$. ft. sheet-iron lining to gutter on main floor.

I sheet heavy galvanized-iron $5^{\prime} \times 6^{\prime} \ldots \ldots \ldots$

I sheet iron flue-cap to $\delta^{\prime \prime}$ flue...........

I2 feet (about) $S^{\prime \prime}$ sheet-iron flue for engine.

II ARDVY ARE.

300 lbs. common nails

50 lbs. finishing nails

3 pairs bronze butts, $4^{\prime \prime} \times 4^{\prime \prime}$, for front doors

4 pairs iron butts, $3 \frac{1}{2}^{\prime \prime} \times 3 \frac{1}{2}^{\prime \prime}$, for other doors

3 strap-hinges, $6^{\prime \prime}$, for ice-room door.......

3 pair butts, $2^{\prime \prime} \times 2^{\prime \prime}$, for coal-room shutter

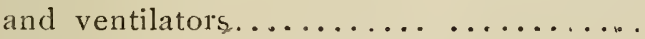

I mortise-lock, $5^{\prime \prime}$, for front door.........

I flush-bolt, for front door ...

4 rim-locks, with keys, $4 \frac{1^{\prime \prime}}{2}$, for other doors..

I set sheaves and $\mathrm{I}_{3} \mathrm{ft}$. rail, for sliding doors

2 common iron bolts, for ice-room door and coal-room shutter................ 
I iron ring, $3^{\prime \prime}$ diam., with bolt staple, for ice-

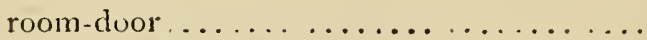

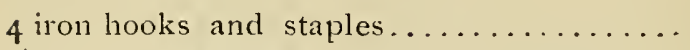

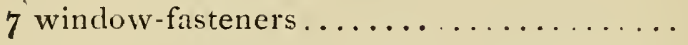

\section{SITUATION OF CREAMERY.}

Building to be built at such place as may be indicated.

\section{REMARKS ON SPECIFICATION.}

It will be remembered, by those using these specifications, that they were made with reference to erecting a creamery at our station; but the great demand from all parts of the State for plans of creamery build ng has prompted us to give, in this bulletin, things that will answer the many inquiries coming from the people.

Should any community or company let the work of building to contractors, they will find it to their interests to use some set of specifications; the main points of which may be obtained from those given.

\section{EXCAVATION.}

In following the specifications given in regard to excaration, the parties will be governed by the situation of the building. It has been found more economical to build on the side of a hill, that as little work as possible may be done in excarating for basement; the amount of earth to be removed depending on the slope of the hill.

\section{MASONRY.}

Stone may be used in the nine-inch partition wall between sce-room and hasement. Should it be cheaper in making floor of basement rooms, it is not necessary for the stone, gravel, etc., forming floor, to be over eight inches thick unless the earth is inclined to be wet and seepy. If walls in basement are built with care, making a comparatively smooth surface, no plastering will be necessary except where there is a tendency for water to seep in through the wall.

FIR AM1NG.

One's own judgment will prompt him to use in framing, whatever kind of timber is best suited to his locality. 
FLOORING.

Specifications should be fully carried out, as all things are essential.

\section{SIDING.}

May be carried out to suit those having work done.

\section{CEILING AND INSIDE WALLS.}

Common six-inch tongued and grooved ceiling may be used for both ceiling and inside wall. The partition between engineroom and main work-room may be of same material as is used in ceiling, the plank running perpendicularly to the floor.

\section{DOORS.}

All doors may be of the same material as is ordinarily used in buildings, with no extra timber of any sort, and locks may be of the common kind.

\section{WINDOWS.}

Weights and pulleys may be omitted. The double window in front may be made into one large window should it be found to be less expensive.

\section{TRANSOMS.}

May or may not be used.

\section{ELEVATOR.}

The construction of elevator will be essentially the same as shown on plans. It will be found to better advantage if onehalf inch cotton rope is used in place of the wire as specified.

\section{TINNING.}

All tinnug on roof may be omitted should it be found to be more economical to use other material that will answer the purpose.

\section{PAINT.}

May he omitted or as much used as will be necessary for preservation.

Building should be centrally located in reference to patrons 
supplying the milk, but cilce must be taken in all cases to see that a sufficient supply of pure spring or well water can be obtained at the creamery. To a certain extent the site of building will be governed by the water supply and the central location must be sacrificed if water supply can not be obtained.

\section{BILL, OF MATERIALS.}

The changes that may be made in this building will necessarily affect the bill of materials as given, and due notice should be taken of any changes madc, and the bill altered to suit the change.

\section{HOW CREAMERIES ARE CONDUCTED.}

A creamery may be conducted either on the co-operative plan or as a private enterprise. In the former case, the farmers erect the building; supply the necessary apparatus, and pay all expenses that they may have a place for manufacturing their produce to be sent to the markets in a form that it will command the highest price. In the latter case, the creamery is owned by a firm who buy the milk from the farmers, paying them a higher or lower price per pound, as the butter market rises or falls. In either case, the farmers deliver their milk twice a day in warm weather and once a lay (in the morning) when the milk can be kept orer night without becoming somr.

In the former plan (co-operitive), there is no middle man to be remunerated for his services as proprietor, but all proceeds, after paying running expenses, go direct to the farmers who furnish the milk; while in the latter case, a part of the returns must be used in paying this middle man.

There is a certain livalry in dairy sections that is almost the life of the business. Every one is engaged in supplying more or less milk to the creancry; hence, each tries to beat his neighbor in both quality and quantity of the product from his corrs. A gain one month over the last inspires one for greater gain and the cows will be milked until the last drop that has been produced has been extracted from the udder.

The monthly settlement is one of the greatest points in faror of the creancry business. Instead of having to wait six months or a y 10 proceeds of the work, as is the case in other styles 
of farming, a settlement is made at the end of each month, enabling the farmers to receive the reward of their labor at short intervals. On settlement day it will be found that two men may have milked the same number of cows, still the two yields will be very different for the thirty clays past. Another point may be noticed, that the man who had delivered the smaller number of pounds of milk may have credit for the greater number of pounds of butter.

MODE AND VALUE OF TESTING.

The part of the routine work known as "testing" is of the utmost importance as it determines the butter value of each man's milk, and according to the test is each man paid for his milk.

It was stated that though two patrons may deliver the same amount of milk, the butter yield of the one might be double that of the other. This difference in quality is determined by the creamery man who subjects a fair sample of each man's milk to a test once in every two days. An example will best explain the value of testing.

A delivered during the month of January 3,000 pounds of milk. About twelve different tests were taken during the time to get at the quality of his milk. Milk is not necessarily of the same richness two days in succession, and one day it may take 26 pounds of milk to make one pound of butter and the next it may take 22, the next 24 and so on through the month. At the end of the month an average is taken of all the tests and it is found to take say 24 pounds of milk to one of butter. 3,000 pounds of milk were delivered during the month and 24 pounds are required to make one pound of butter; hence, according to test yield, A should receive payment for 125 pounds of butter.

In testing small quantities of milk, we are more apt to get at exactly the amount of butter-fat contained than when large quantities are churned; or rather I should say that when large quantities of cream are churned we cannot get out all the butter that it contains; hence, the actual yield or the aggregate of all the butter made in the creamery during the month will be less than what would have been obtained could every particle of butter-fat be taken from the milk. 
Each patron's milk is tested in the same manner as was A's.

B's test called for $100 \mathrm{lbs}$. of butter, C's for $150 \mathrm{lbs}$, D's for 140 lbs., and so on for all the patrons.

The total test yield or the amount of butter that should be made according to the different tests will almost invariably be larger by 50 or more pounds than the actual yield, and he is a good creamery man who makes the actual yield equal to the test yield.

A simple proportion used to reduce the different amounts of butter as called for by test yield to the exact test yield is:

Total test yield is to each man's share, or using the figures assumed, we have supposing there was made at the creamery (actual yield) 3,000 pounds of butter. According to the tests, there should be $3,05^{\circ}$, and according to A's test he should re. ceive 150 pounds. Then-

Total test yield. A's test yield. Actual test yield. A's actual share. $3050 \quad: \quad$ 1 $50 \quad:$ : $3000 \quad$ : $x, A$ 's share.

$\mathrm{x}=147.5$, and by a similar ratio each patron's share is determined.

This testing is the only means of getting at the quality of milk and what is practiced at the creamery may be done at home with the clairy herd.

- Each cow should be tested and there will be found in every herd one or two that do not pay for the food consumed.

We cannot afford to keep in our herd such cows, for it is evident that they are kept at a loss, consuming food and not making.butter enough to pay for it.

Dairying like all other farming is subject to close competition and the accepted law of the "survival of the fittest" ap. plies to this as well as to all progressive things.

We must not keep cows that will not pay for food and labor, but must free ourselves of them and have none but good milkers, quality rather than quantity beins considered.

Could a regular scale be made out, putting in logical order the most important things of a dairy herd, I should say: first in importance is breed. Food and care are so closely connected, being mutually dependent, that it would be hard to say which should be placed first. Good food and poor care or poor food 
and good care are about equal; but as it is expected to have both good food and good care, I would say second in the scale food, and third care.

On these three factors, breed, food and care, together with the energy and enterprise of the farmer, depends the success or failure of all who engage in the creamery industry.

\section{PLAN OF ORGANIZATION.}

It is a well known fact that $n$ enterprise, however simple, can make even fair progress without some guide or head. Neither can a community expect to do anything in the Creamery business unless some of the enterprising men take the matter in charge; see to perfecting an organization of the farmers; electing a President, Secretary, etc., and appointing committees to probe the whole subject to the core.

No one plan that could be suggested would suit every community; but the following is given, it being the way that we have succeeded in getting several organizations in different parts of the State. Have it generally understood that on a certain day, at a certain place and hour, those interested in the improvement of their interests are to meet to discuss the advisability of engaging in the Creamery business. An energetic man should be made President of the organization, another made Secretary, and a committee should be appointed to ascertain the number of cows that can supply milk to the Creamery. This would complete the business of the first meeting, and another day for meeting should be appointed. Before the time of second meeting, the subject can be discussed privately by all the parties, while the committee appointed gets the necessary data in regard to the number of cows. The Secretary can inform the Station of the action of the organization, and if it is desirable on the part of the farmers and arrangements can be made at the Station, one of the Staff will go to the second meeting and give any assistance that can be retrdered. If a company is formed, or if a private party desires to go into the business as an investment, the Station will, as I have said, send a man to any community in the State to adjust the machinery and stay in that community a month or so and instruct one whom the company may choose, in the art of 
manufacturing Creamery butter, and in running a Creamery in first-class style. This assistance, it must be understood, is given free of all charge to the company or private party engaging in the business.

WHAT IS THE ADVANTAGE OF A CREAMERY IN A COMMUNITY?

We have given, in this Bulletin, all points that are essential to be known before starting in the Creamery business. Comparisons have been made to bring before the farmer's eyes the condition of agriculture in our own State. List and cost of apparatus for Creamery is given; plan of building suggested and to those who resolve to go into the business, the Station will send a man to adjust all machinery and instruct one whom the people may choose in the art of manufacturing Creamery butter. This we do free of all cost to the company or private party building the Creamery.

Why do we put this whole matter before the farmers of our State? And why do we offer the services of the Station's Staff free of all charge? Because we believe it to be one of the most important factors, should it be carried out, in solving the problem of redemption of worn out soils and the utilization of our hillsides.

The assertion is made withont fear of successful contradiction that in no enterprise can the farmers engage that will return to them, in a shorter time, the capital invested than will the Creamery business. The mode of operation of a Creanery explains how this is. Suppose $\$ 500$ is invested in dairy cows. This will purchase at least eight that will bear the record already given. Eight cows which will in one month produce, according to the foregoing figures, butter to the amount of $\$ 3{ }_{3} S .24 \mathrm{cts}$. and this is at the rate of $7 S$ per ct. interest on investment. In what other business can our farmers engage that will pay such a per ct. on investment and declare a dividend each month?

It has been stated by one of the leading men in Ontario, Canada, that the dairy undustry has advanced the farming interests of that section far more than the people thought. Several countries have been made productive and wealthy by increasing the fertility of exhansted soils. Farmers who had 
bought poor lands had, by this system of utilizing the farm, increaser them in value Ioo per cent. By thus making these lands valuable $\$ 9,000,000$ had been added to that country within one year and not one bushel less of wheat or other grains had been grown. Thus a di:"ect gain. The industry had developed a market for the coarser products of the farm and a crop of oat straw was much enhanced in value. It also made provision for human food, which would otherwise be wasted. The farmer's occupation is to produce everything for all his wants. In the clairy business, all these foods were utilized or made fit for human food. A mail could live on straw or hay, so to speak, for these were converted into nutriment fit for use in the human body, and five times the population could be supported by dairying tnan by any other system of farming. In proof of this, it was found that dairy districts were more thickly populated than where a mixed husbandry was practiced; thus, property in those sections increased in value and a permanent prosperity was established. Three-fourths of the food consumed came from dairy farming; beef, pork and poultry are mainly the outcome of dairy farming. All in all, dairy farming has done more for the country than all the emigration agents and speeches for many years.

We would not have you believe that there is little labor connected with this style of farming; but on the other hand, wuold forewarn those who have any idea of engaging in this enterprise, that with it is connected labor, and that of an intelligent character; but we do believe it to be the road to success where we are dependent upon the farm for our support. 
